\title{
EHMTI-0174. Dural vessel hemodynamics during normal behavior and migraine attack
}

\author{
Y Gao ${ }^{1 *}, \mathrm{P}$ Drew $^{2}$ \\ From 4th European Headache and Migraine Trust International Congress: EHMTIC 2014 \\ Copenhagen, Denmark. 18-21 September 2014
}

\section{Introduction}

Migraine is hypothesized to be caused by the pathological dilation of blood vessels in the dura.

\section{Aims}

To better understand the vascular pathology of migraine, we measured dural vessel diameter changes during normal behavior and under pharmacologically-induced migraine attack in awake behaving mice.

\section{Methods}

We use two-photon laser scanning microscopy (2PLSM) to concurrently measure dural and pial surface vessel diameters down to micrometer resolution. Measurements were made in the somatosensory cortex of awake, headfixed mice on a spherical treadmill, which allowed the mice to voluntarily run.

\section{Results}

A majority of the dural vessels constricted during locomotion $(\mathrm{n}=29$ vessels in 11 mice, peak constriction $=-11.2 \%$ $\pm 5.7 \%$ ), some of them did not respond (8 vessels in 4 mice), while there were a few dilated (3 vessels in 2 mice, peak dilation $=12.2 \% \pm 3.3 \%$ ). In the contrast, all the pial vessels dilated during locomotion, with arteries showing rapid and large dilation $(19.7 \% \pm 8.2 \%)$ and veins showing a slower and smaller dilation $(6.6 \% \pm 3.2 \%)$. Preliminary experiment shows that injecting CGRP, which is believed to provoke migraine, drives the dilation of dural vessels.

\section{Conclusions}

Dural vessels exhibit diverse dynamics during locomotion, but the dominant effect was constriction. The differences between dural and pial vessels have never been reported before, but may indicate a unique function of dural vessels

${ }^{1}$ Neuroscience Program, Pennsylvania State University, University Park, USA Full list of author information is available at the end of the article during exercise. This work provides novel insights into the normal dynamics of dural vessels during behavior and their disfunction during migraine.

No conflict of interest.

\section{Authors' details}

${ }^{1}$ Neuroscience Program, Pennsylvania State University, University Park, USA. ${ }^{2}$ Dept. Engineering Science and Mechanics \& Dept. Neurosurgery, Pennsylvania State University, University Park, USA.

Published: 18 September 2014

doi:10.1186/1129-2377-15-S1-A2

Cite this article as: Gao and Drew: EHMTI-0174. Dural vessel

hemodynamics during normal behavior and migraine attack. The Journal of Headache and Pain 2014 15(Suppl 1):A2.

\section{SpringerOpen ${ }^{\odot}$}

(c) 2014 Gao and Drew; licensee Springer. This is an Open Access article distributed under the terms of the Creative Commons Attribution License (http://creativecommons.org/licenses/by/2.0), which permits unrestricted use, distribution, and reproduction in any medium, provided the original work is properly cited.

Submit your manuscript to a SpringerOpen ${ }^{\circ}$ journal and benefit from:

- Convenient online submission

- Rigorous peer review

- Immediate publication on acceptance

- Open access: articles freely available online

- High visibility within the field

- Retaining the copyright to your article

Submit your next manuscript at $>$ springeropen.com 